\title{
Alergija antibakteriniams vaistams
}

\author{
Doc. dr. Palmira Leišytè \\ KMU Vidaus ligų klinika
}

Reikšminiai žodžiai: antibiotikas, alergija, diagnostika.

Santrauka. Straipsnyje aptarti alergijos betalaktaminiams antibiotikams diagnostikos bendrieji principai. Atkreiptas dèmesys į alerginių reakcijų antibiotikams klasifikaciją (greitąsias ir negreitąsias reakcijas), padedančią pasirinkti diagnostinius tyrimus, ịvertinti kryžmiškumo dažnumą. Greitosios ir negreitosios alerginès reakcijos antibiotikams skiriasi imuniniais mechanizmais, klinikiniais požymiais, diagnostika, prognoze.

Šiuo metu apie 10-20 proc. hospitalizuotu pacientuc ir daugiau kaip 7 proc. visos populiacijos patiria nepageidaujamą vaistų poveikị. Tai mįslingiausia ir pavojingiausia problema klinikinejje alergologijoje. Daug klausimu ir tik keletas atsakymų, teigia prof. W. Pichler (Šveicarija) - pripažintas autoritetas tarp alergijos vaistams tyrejjų.

Diagnostikos sudètingumą sąlygoja padidejjusio jautrumo reakcijų vaistams vystymosi skirtingi mechanizmai. Vaistai gali sukelti visų imuninių tipų reakcijas, aprašytas Gell ir Coombs. Būdingos ir neimuninès padidèjusio jautrumo (pseudoalerginès) reakcijos. Konkrečiai žinoma tik keletas vaisto alergeno determinančiuc ir tiksliau nustatyta tik keletas išsivystymo mechanizmų. Taigi klinikinejje praktikoje pasirenkami diagnostikos metodai ne visada būna pakankamai jautrūs ir specifiški. Renkama informacija apie individualią riziką būti alergiškam vaistams atsižvelgiant i farmakologinius (pvz., CYP450 metabolizmo kelią) ir imuninius veiksnius. Nors identifikuota keletas rizikos veiksnių, jų klinikinė reikšmė nėra iki galo suprasta.

Tikimasi, kad tobulejanti imunogenetika, farmakogenetika padés nustatyti $\mathfrak{i}$ vaistų sukeliamas specifines reakcijas linkusias populiacijas. Alergijos vaistams srityje aktyviai dirba ekspertu grupés, vykdomi projektai WONDA (angl. World Network for Drug Allergy), EUROSCAR, GERAP, ENDA (angl. European Network for Drug Allergy).

\section{Nepageidaujamų reakcijų ị vaistus klasifikacija}

1. Su vaistais susijusios reakcijos:

- padidejusio jautrumo reakcijos;

- perdozavimas;

- nepageidaujamas šalutinis poveikis vartojant terapines vaisto dozes;

- nepageidaujamas poveikis dèl vaistų sąveikos.

2. Su vaistais nesusijusios reakcijos (psichogeninès, atsitiktinio sutapimo reakcijos).

Ittarus nepageidaujamą reakciją i vaistą, būtina surinkti išsamią anamnezę, kad būtų atsakyta ì pagrindinius klausimus:

- Ar reakcijos kaltininkas yra vaistas, o gal tai infekcinè ar autoimuninè liga?

- Ar tai alerginè reakcija ar kitas nepageidaujamas vaisto poveikis?

- Kuris vaistas ar jo sudedamoji dalis yra medikamentinès alergijos priežastis?

- Kokių grupių vaistai gali sukelti kryžmines alergines reakcijas konkrečiam ligoniui?

- Kokius vaistus saugu skirti, kad jie būtų veiksmingi konkrečios patologijos atveju?

Daugiausia pasiekta tyrinejjant alergiją beta laktaminiams antibiotikams. Žinoma, kad alergiją antibakteriniams vaistams skatina kartu esanti virusinè infekcija: ŽIV, Citomegalo viruso, Herpeso viruso, Epšteino-Baro viruso. 
Klinikiniu požiūriu tikslinga alergines reakcijas beta laktamams skirti i greitąsias ir negreitąsias. Renkant anamnezę, būtina išsiaiškinti:

- intervalą tarp pirmos vaisto dozès ir paskutinès vartotos vaisto dozès;

- intervalą tarp paskutinès vartotos vaisto dozès ir klinikinių simptomų atsiradimo;

- simptomų pobūdí.

Greitosios reakcijos pasireiškia per pirmąją valandą po vaisto suvartojimo, jos linkusios praeiti, kai vaisto ilgai nebevartojama (nors galima ir resensibilizacija). Greitosioms reakcijoms būdingi požymiai: 1) dilgèlinè ir/ar angioedema, 2) anafilaksija (delnų, padų niežejjimas, generalizuota eritema, rinitas, bronchų spazmas, anafilaksinis šokas). Greitosios reakcijos - tai su IgE susijusios reakcijos.

Negreitosios (vėlyvosios, uždelstos, lètosios) reakcijos pasireiškia praejus daugiau kaip vienai valandai po vaisto suvartojimo (1-48 val.). Negreitosioms reakcijoms būdinga ilgalaike įsijautrinimo būklè. Tai reakcijos susijusios su T limfocitais. Šios reakcijos pasireiškia:

- makulopapuline (morbiliformine) egzantema;

- vèlyva dilgèline/angioedema;

- eksfoliaciniu dermatitu;

- ūmine generalizuota egzantemine pustulioze (AGEP);

- sunkiomis pūslinėmis egzantemomis (SJS, TEN);

- erythema multiforme;

- erythema fixatum;

- kontaktiniu dermatitu;

- DRESS sindromu.

\section{GREITUৃJŲ ALERGINIŲ REAKCIJŲ I BETA LAKTAMINIUS ANTIBIOTIKUS KLINIKINĖ DIAGNOSTIKA}

Greitųjų alerginių reakcijų diagnostikai taikomi odos dūrio mèginiai, ịodiniai mėginiai, provokaciniai mėginiai. Galima diagnostika in vitro: specifinių IgE nustatymas (RIA, FEIA), bazofilų aktyvumo žymenų tyrimai.

Dūrio ir íodiniams méginiams gali būti naudojami komerciniai preparatai: penicilloylpolylysine (PPL), mažuju determinančiu mišinys (MDM) bei vaistai: benzilpenicilinas (BP), aminopenicilinai (amoksicilinas (AX), ampicilinas (AM)), kiti penicilinai, cefalosporinai. Odos mėginiams atlikti naudojamos vaistu koncentracijos pateiktos lentelèje.

Lentelè. REKOMENDUOJAMOS HAPTENU KONCENTRACIJOS ODOS MÉGINIAMS ATLIKTI

\begin{tabular}{lll}
\hline Preparatas & $\begin{array}{l}\text { Pradinė } \\
\text { koncentracija }\end{array}$ & $\begin{array}{l}\text { Didžiausia } \\
\text { koncentracija }\end{array}$ \\
\hline PPL & $1: 10$ & neskiestas \\
\hline MDM & $1: 100$ & neskiestas \\
\hline $\mathrm{BP}$ & $100 \mathrm{TV} / \mathrm{ml}$ & $10000 \mathrm{TV} / \mathrm{ml}$ \\
\hline $\mathrm{AM}, \mathrm{AX}$ & $1-2 \mathrm{mg} / \mathrm{ml}$ & $20-25 \mathrm{mg} / \mathrm{ml}$ \\
\hline Kiti penicilinai & $1 \mathrm{mg} / \mathrm{ml}$ & $20 \mathrm{mg} / \mathrm{ml}$ \\
\hline Cefalosporinai & $2 \mathrm{mg} / \mathrm{ml}$ & - \\
\hline
\end{tabular}

Atliekant méginius, būtina neigiama kontrolè fiziologinis tirpalas bei šviežiai paruoštas praskiestas vaistas. Odos mėginiu specifiškumas - 97-99 proc., jautrumas atliekant méginius su keturiais haptenais 70 proc. Jei odos méginiai teigiami, pacientas laikomas alergišku. Tačiau vien odos méginiais atmesti alergijos negalima. Kuo daugiau laiko praeina nuo buvusios reakcijos iki odos mėginiu atlikimo, tuo didesnè tikimybè, kad odos mėginiai bus neigiami. Todèl alergiškiems pacientams išsiaiškinti atliekami testai in vitro, specializuotuose centruose atliekami provokaciniai méginiai. Jei nežinoma, kuris beta laktaminis vaistas sukèlè alerginę reakciją, amoksicilinas yra dažniausiai pasirenkamas vaistas provokaciniam méginiui atlikti.

Pasiūlytas toks greitosios alerginès reakcijos beta laktaminiams vaistams diagnostikos algoritmas: jei mėginys su BP pagrindinėmis determinantėmis (PPL, MDM) teigiamas, laikoma, kad yra neselektyvus jautrumas beta laktaminiams vaistams, o jei méginys neigiamas, - reikia ieškoti selektyvios alergijos.

\section{KRYŽMINIS REAKTYVUMAS ESANT GREITOSIOMS ALERGINĖMS REAKCIJOMS I BETA LAKTAMINIUS ANTIBIOTIKUS}

Pastebima, kad tarp penicilinų ir I klasès cefalosporinų kryžmiškumas yra dažnas, o tarp penicilinų ir II bei III klasės cefalosporinų retas. Cefalosporinu pavyzdys rodo, kad kryžmiškumas nẻra dvipusis reiškinys. Cefalosporinui jautrius pacientus galima skirti $\mathfrak{i}$ šias grupes:

- jautrius ir cefalosporino, ir penicilino determinantei;

- jautrius tik cefalosporino determinantei, todèl toleruojančius benzilpeniciliną;

- jautrius tik vienam konkrečiam cefalosporinui.

Galima selektyvi alergija ir amoksicilinui (esant specifiškam jautrumui beta laktamo šoninei grandinei). Šiu pacientų alergijos raida skiriasi: grupeje pacientų, jautrių bendrai penicilino determinantei, po penkerių metų nejautrūs tapo tik 40 proc., o pacientų, kurie buvo jautrūs tik amoksicilinui, po penkerių metu net 100 proc. buvo gauti neigiami odos méginiai. Iš šio tyrimo liko neaišku, ar neigiami odos mėginiai prilygsta alergijos nebuvimui.

Kryžminis reaktyvumas tarp penicilinų ir karbapenemų (imipenemo, meropenemo) - retas reiškinys. Nèra akivaizdžių duomenų apie kryžminį reaktyvumą su monobaktaminiais preparatais.

Pacientai gali būti:

- jautrūs visiems beta laktaminiams antibiotikams;

- jautrūs pogrupiui vaistų su panašia šonine grandine;

- jautrūs tik vienam antibiotikui.

Taigi, jei yra alergija vienam beta laktaminiam antibiotikui, dar nereiškia, kad negalima skirti kitu beta laktaminių vaistų. Svarbu išsiaiškinti, ar tai tik selektyvus jautrumas ar gali būti kryžminè alerginė reakcija. 


\section{NEGREITŲJŲ ALERGINIŲ REAKCIJŲ I BETA LAKTAMINIUS ANTIBIOTIKUS KLINIKINĖ DIAGNOSTIKA}

Esminis vaidmuo tenka anamnezei. Atliekami ir odos mėginiai (Łodiniai, lopo). Lopo mėginiai naudingi kartu atliekant vėlyvojo vertinimo (po 24, 48, 72 val.) țodinius mėginius. Iodiniai méginiai jautresni už lopo méginius, tačiau mažiau specifiški. Lopo mėginiai atliekami su BP, AM, AX, cefalosporinais. Odos méginių jautrumas yra gana mažas, todèl reikšmingesni provokaciniai mėginiai. Jie atliekami su įtariamu vaistu arba alternatyviu antibiotiku ịsitikinti jo saugumu.

Specializuotuose centruose galima diagnostika in vitro (atliekamas LTT - limfocitu transformacijos testas/limfocituc proliferacinio atsako ị vaistą tyrimas).

\section{KRYŽMINIS REAKTYVUMAS ESANT NEGREITOSIOMS ALERGINĖMS REAKCIJOMS I BETA LAKTAMINIUS ANTIBIOTIKUS}

Apie 70 proc. pacientų, jautrių aminopenicilinams, nereaguoja ị benzilpeniciliną (atliekant odos méginius).
Esant negreitosioms, T limfocitų sąlygotoms alerginėms reakcijoms, kryžmiškumas tarp cefalosporinų ir penicilinu taip pat pasitaiko labai retai.

\section{ALERGINĖS REAKCIJOS İ NE BETA LAKTAMINIUS ANTIBIOTIKUS}

Alerginès reakcijos ị ne beta laktaminius antibiotikus ištyrinètos palyginti mažai. Nustatyta, kad chinolonai sukelia greitąsias IgE sąlygotas alergines reakcijas, pasireiškiančias anafilaksija. Tačiau odos mėginiai nèra tokie patikimi, kaip esant alergijai beta laktaminiams antibiotikams. Daug vilčiuc teikiama diagnostikai in vitro. Tarp chinolonų gana dažnos kryžminès reakcijos, todèl, diagnozavus alergiją chinolonų grupès antibiotikui, rekomenduojama vengti visu chinolonų.

Taigi, ittarus alergiją antibakteriniams vaistams, galimos dvi alternatyvos: siekti tikslios diagnostikos ir tinkamo vaisto parinkimo arba gydyti kitokios cheminès struktūros antibiotiku. Pirmuoju atveju gydytojas sugaišta daug laiko, antruoju - skiriamas brangesnis, o kartais ir ne toks veiksmingas ar toksiškesnis vaistas.

\section{ALLERGY TO ANTIBACTERIAL DRUGS}

\author{
PALMIRA LEIŠYTÉ \\ CLINIC OF INTERNAL DISEASES \\ KAUNAS UNIVERSITY OF MEDICINE
}

Key words: antibiotic, allergy, diagnosis.

Summary. The practical classification of allergic reactions to betalactams are presented. According to this classification (immediate reactions and nonimmediate reactions) different methods of allergy diagnosis are recommended. Immediate and nonimmediate reactions differ in immune mechanisms, clinical manifestations, cross-reactivity, prognosis.

\section{LITERATŪRA}

1. Blanca M, Romano A, Torres MJ et al. Update on the evaluation of hypersensitivity reactions to betalactams. Allergy 2009;64 (2): 183-193.

2. Campi P, Pichler WJ. Quinolone hypersensitivity. Curr Opin Allergy Clin Immunol 2003; 3: 275-281.

3. Rodriguez-Bada JL, Montanez MI, Torres MJ et al. Skin testing for immediate hypersensitivity to betalactams: comparison between two commercial kits. Allergy 2006; 61(8): 947-951.

4. Torres MJ, Blanca M, Fernandez J et al. Diagnosis of immediate allergic reactions to beta-lactam antibiotics. Allergy 2003; 58(10): 961-972.

5. Torres MJ, Sanchez-Sabate E, Alvarez J et al. Skin test evaluation in nonimmediate allergic reactions to penicillins. Allergy 2004; 59(2): 219-224.

6. Romano A, Blanca M, Torres MJ et al. Diagnosis of nonimmediate reactions to ß-lactam antibiotics. Allergy 2004; 59(11): 1153-1160.

7. Aberer W, Bircher A, Romano A et al. Drug provocation testing in the diagnosis of drug hypersensitivity reactions: general considerations. Allergy 2003; 58(9): 854-863. 